\title{
Phylogenetic Study of Genus Haliotis in Korea by Internal Transcribed Spacer Sequence (ITS)
}

\author{
Man Kyu Huh*, Jung Ho Kim ${ }^{1}$ and Du-Ho Moon ${ }^{1}$ \\ Department of Molecular Biology, Dongeui University, 995 Eomgwangno, Busanjin-gu, Busan 614714, Korea \\ ${ }^{1}$ Biological Education, Busan National University, Busan 607-735, Korea
}

Received June 27, 2008 /Accepted August 10, 2009

\begin{abstract}
Abalone (genus Haliotis) is a woody species with a long life span that is primarily distributed throughout the world, including Asia. This species is regarded as a very important marine gastropod mollusk in Korea and China, and also in food industries around the world. We evaluated a representative sample of the five species with nuclear ribosomal DNA internal transcribed spacer sequences (ITS) to estimate genetic relationships within the genus. Aligned nucleotide sequences of the length of the $5.8 \mathrm{~S}$ subunit of all taxa of Haliotis were found to constant of $160 \mathrm{bp}$ nucleotides. However, aligned nucleotide sequences of the length of ITS1 were varied within genus Haliotis, varying from 272 in $H$. diversicolor aquatilis to 292 in $H$ discus hannai. Aligned nucleotide sequences of the length of ITS2, especially, vary from 722 in $H$ diversicolor aquatilis to 752 in $H$. sieboldii. Total alignment length is 763 positions, of which 78 are parsimony-informative, 57 variable but parsimony-uninformative, and 459 constant characters. $H$. discus hannai was similar to $H$. discus, while $H$. diversicolor aquatilis was more distinct. ITS analysis may be useful in germ-plasm classification several taxa of genus Haliotis.
\end{abstract}

Key words : Abalone, Haliotis, ITS, phylogenetic analysis

\section{Introduction}

Determination of DNA sequence heterogeneity can provide useful taxonomic information on intra- and inter-specific genetic variation in animals. In order to development a rapid, taxonomically useful system to define intraand inter-specific DNA sequence variation we have used the polymerase chain reaction (PCR) to amplify DNA fragments displaying sequence heterogeneity. The PCR has been used to isolate and sequence specific regions of genetic variation from within the genome [22].

Nuclear ribosomal DNA internal transcribed spacer sequences (ITS) is eukaryotic ribosomal RNA genes (known as ribosomal DNA or rDNA) are found as parts of repeat units that are arranged in tandem arrays, located at the chromosomal sites known as nucleolar organizing regions (NORs) [1]. Each repeat unit consists of a transcribed region (having genes for 18S, 5.8S and 26S rRNAs and the external transcribed spacers i.e. ETS1 and ETS2) and a non-transcribed spacer (NTS) region. In the transcribed region, internal transcribed spacers (ITS) are found on either side of 5.8S rRNA gene and are described as ITS1 and ITS2. The

\section{*Corresponding author}

Tel : +82-51-890-1529, Fax : +82-51-890-1521

E-mail : mkhuh@deu.ac.kr two internal transcribed spacers (ITS1 and ITS2) have been shown to be relatively valuable targets for defining markers in systematic studies [16]. In fact, ITS1 and ITS2 have proven useful for resolving phylogenies of closely related taxa that have diversed relatively recently ( $<50$ million years ago) and are excellent markers for species distinction, since they are relatively fast evolving sequences [2,18]. Universal PCR primers designed from highly conserved regions flanking the ITS and its relatively small size (600-700 bp) enable easy amplification of ITS region due to high copy number (up to-30000 per cell) of rDNA repeats [7].

Abalone (family Haloitidae) are marine gastropod mollusks a worldwide distribution in coastal temperate and tropical waters [5]. There are about 55-60 recognized species of Haliotis in the world $[9,10,13]$. The genus has a considerable literature concerning gamete affinities and cross-fertilization among species, an aspect of species biology particularly interesting to compare to a phylogenetic reconstruction based on ITS sequences [4]. Furthermore, Haliotis is the only animal genus for which DNA sequences are available from multiple species for two gene products. One is the DNA sequence on the sperm and the other on the egg. They are interacted at a major step in gamete recognition at fertilization [19].

Many species of Haliotis had been used from the example 
Table 1. Codes and locations of Haliotis species used in this study

\begin{tabular}{llc}
\hline Species & Localities & Code \\
\hline Haliotis discus hannai Reeve & Bogil-myeon, Woando-gun, Chonlanam-do & HAN \\
H gigantea Gmelin & Samyang-dong, Jeju-shi, Jeju-do & GIG \\
H sieboldii Reeve & Sinchang-ri, Hangeong-myeon, Bukjeju-gun, Jeju-do & SIE \\
H discus discus Reeve & Iho, Jeju-shi, Jeju-do & DIS \\
H diversicolor aquatilis Reeve & Sinchang-ri, Hangeong-myeon, Bukjeju-gun, Jeju-do & DIV \\
\hline
\end{tabular}

for good materials for food and according as new research and practical use way about medical use and so on are risen, as the availability also is increased, the importance and edibility as resources.

The genus Haliotis was chosen for this study for three reasons. First is to assess the usefulness of ITS sequences for reconstructing the phylogenetic history of an animal group. Second is to compare the ITS results with known hybridization data for the same species. Finally, Coleman and Vacquier [4] used ITS sequence to study the phylogenetic relationships within genus Haliotis. In their investigations, only $H$. divericolor supertexta from Taiwan are suggested, one with the Taiwan Haliotis species and the eastern Asian abalone. DNA sequence analyses comprising many Asian species from the most important diversity center of the genus have not yet been carried out thus far.

The purpose of this research is to do molecular data support the current classification of the species within the genus Haliotis in Korea. In addition, molecular evidence assumes an important role in phylogenetic reconstruction of species in this genus.

\section{Materials and Methods}

\section{Animals and DNA extraction}

The specimens of Haliotis discus hannai, Haliotis discus, $H$. sieboldii, $H$ gigantea, and $H$. diversicolor aquatilis were collected from five populations in Korea (Table 1). Tissue and DNA were from same animals. DNA extracts from tissue of a specimen each of species. Individual abalones were isolated without food, in an antibiotic solution (ampicillin 100 $\mu \mathrm{g} / \mathrm{ml}$ ) and left overnight at $4^{\circ} \mathrm{C}$ to minimize prokaryotic growth prior to DNA extraction. The protocol to obtain ITS sequences was similar to that utilized previously with some modification [3,6]. Briefly, muscle tissues were ground in nitrogen gases and added $20 \mu \mathrm{l}$ proteinase $\mathrm{K}(10 \mu \mathrm{g} / \mu \mathrm{l})$. The mixture incubated at $55^{\circ} \mathrm{C}$ for $4 \mathrm{hr}$ and added $2 \mu \mathrm{l}$ RNase $(10 \mu \mathrm{g} / \mu \mathrm{l})$ at $37^{\circ} \mathrm{C}$ for $5 \mathrm{~min}$. Nucleic acids were extracted by adding phenol : chloroform : isoamylalcohol (25:24:1) and shaken for $2 \mathrm{~min}$. The aqueous layer was collected by centrifugation and transferred into a new tube containing 250 $\mu \mathrm{l}$ of absolute ethanol and $10 \mu \mathrm{l}$ of $3 \mathrm{M}$ sodium acetate. Genomic DNA was pelleted, after incubation at $-70^{\circ} \mathrm{C}$ for $30 \mathrm{~min}$, by centrifugation and washed in $70 \%$ ethanol to remove excess salts, vacuum dried and then re-dissolved in $12 \mu \mathrm{l}$ TE buffer (10 mM Tris-HCl, pH 8.0, 1 mM EDTA, pH 8.0) and subsequently stored at $4^{\circ} \mathrm{C}$. DNA was checked for shearing and concentration by agarose electrophoresis and fluometry respectively.

\section{ITS analysis}

Primer sets of about 20 bases in length (ITS1 and ITS2) [23] were used for PCR analysis (Table 2). These primers were based on well-characteristic DNA Sequences and were designed making use of conserved regions of the $18 \mathrm{~S}$ and $28 \mathrm{~S}$ rRNA genes to amplify the noncoding regions between the (ITS1 and ITS2) and 5.8S rRNA gene.

PCR materials ( $50 \mu \mathrm{l}$ volume) included $50 \mathrm{ng}$ of genomic DNA, $100 \mathrm{uM}$ of each dNTP, $0.2 \mathrm{uM}$ of each primer, $1 \mathrm{x}$ enzyme buffer, and 2 unit of Taq polymerase. The amplification profile was 28 cycles of $94^{\circ} \mathrm{C}$ for $30 \mathrm{sec}, 42^{\circ} \mathrm{C}$ for 60 sec, $72^{\circ} \mathrm{C}$ for $60 \mathrm{sec}$, preceded by an initial denaturation at $94^{\circ} \mathrm{C}$ foe $90 \mathrm{sec}$ and followed by a final extension at $72^{\circ} \mathrm{C}$ for $5 \mathrm{~min}$.

PCR products were separated on $1.5 \%$ agarose gels and purified using the QIAquick Gel Extraction Kit (QIAGEN). The amplified fragments were cloned into a bluescript vector and sequenced using ABI Prism 377 Sequencer (Applied

Table 2. Synthetic primer $\left(5^{\prime}-3^{\prime}\right)$ used for sequencing the ITS gene in genus Haliotis taxa

\begin{tabular}{ccc}
\hline No. & \multicolumn{1}{c}{ Primer } & \multicolumn{1}{c}{ Reference } \\
\hline ITS1 & TCCGTAGGTGAACCTGCGG & White et al. [23] \\
ITS2 & GCTGCGTTCTTCATCGATGC & White et al. [23] \\
ITS3 & GCATCGATGAAGAACGCAGC & White et al. [23] \\
ITS4 & TCCTCCGCTTATTGATATGC & White et al. [23] \\
\hline
\end{tabular}


Biosystem, USA). At least ten individuals' clones of each taxon were analyzed.

\section{Phylogenetic analysis and RNA secondary structure}

A pairwise alignment was calculated using the ClustalX program. Phylogenetic relationship were estimated by MEGA4 version 4.0 [20] treating all alignment gaps as missing. A maximum parsimony tree (MP) was inferred using heuristic search, branch-swapping options and tree bisection-reconnection. Confidence values for individual branches were determined by a bootstrap analysis with 100 repeated sampling of the data. In addition, a phylogenetic tree was constructed by the neighborjoining (NJ) method [17] using the NEIGHBOR program in PHYLIP version 3.57 [8].

\section{Results}

ITS profiles for five species of Haliotis were shown in Figure 1. DNA sequencing of ITS1, 5.8S, and ITS2 were successful in all of the species given in Table 3 .

Aligned nucleotide sequences of the length of ITS1 were varied within Haliotis varying from 272 in $H$ diversicolor aquatilis to 292 in $H$ discus hannai. Especially, the $5.8 \mathrm{~S}$ subunit of all taxa of Haliotis was found to constant of $160 \mathrm{bp}$ nucleotides. Aligned nucleotide sequences of the length of

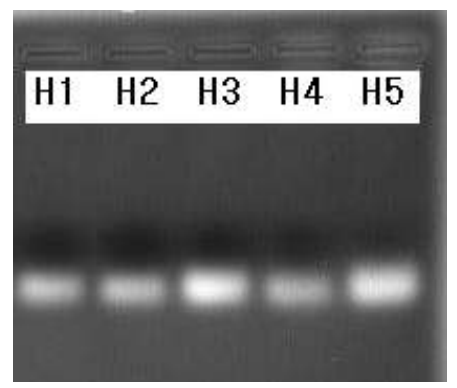

Fig. 1. ITS profiles of five species genus Haliotis in Korea. H1: Haliotis discus hannai, $\mathrm{H} 2$ : H gigantea, $\mathrm{H} 3$ : $H$. sieboldii, $\mathrm{H} 4$ : $H$ discus, H5: $H$ diversicolor aquatilis.

Table 3. Sizes of ITS-1, 5.8S and ITS-2 regions of genus Haliotis

\begin{tabular}{ccccc}
\hline Codes & ITS- 1 & $5.8 S$ & ITS-2 & Total \\
\hline HAN & 292 & 160 & 298 & 750 \\
GIG & 275 & 160 & 298 & 733 \\
SIE & 294 & 160 & 298 & 752 \\
DIS & 288 & 160 & 298 & 746 \\
DIV & 272 & 160 & 290 & 722 \\
\hline
\end{tabular}

The codes of HAN, GIG, SIE, DIS, and DIV are the same as Table 1.
ITS2 vary from 722 in $H$ diversicolor aquatilis 752 in $H$ sieboldii.

Total alignment length is 763 positions, of which 78 are parsimony-informative, 57 variable but parsimony-uninformative, and 459 constant characters. The base furtherance showed the difference to the by a total taxon (Table 4): an average $\mathrm{A}$ and $\mathrm{C}$ are $16.9 \%$ and $21.3 \%$ and $\mathrm{G}$ and $\mathrm{T}$ are $24.1 \%, 37.8 \%$, respectively. The base furtherance of $\mathrm{G}+\mathrm{C}$ was showed about $45.4 \%$. The content of $\mathrm{T}$ is most high to $37.8 \%$ in Haliotis.

$H$. diversicolor aquatilis showed the highest number of different bases between all the sequences studied (Table 5).

Genetic identity $(I)$ based on the proportion of shared fragments was used to evaluate relatedness among species. The estimate of $I$ ranged from 0.040 to 0.887 (Table 6).

Table 4. Rate of A, C, G, T to four spices of genus Haliotis using ITS

\begin{tabular}{ccccc}
\hline Codes & A & C & G & T \\
\hline HAN & 16.6 & 26.4 & 25.5 & 31.5 \\
SIE & 22.3 & 20.8 & 26.2 & 30.7 \\
DIS & 16.3 & 20.4 & 20.4 & 42.9 \\
GIG & 14.8 & 19.3 & 24.0 & 42.6 \\
DIV & 14.7 & 19.6 & 24.6 & 41.1 \\
Mean & 16.94 & 21.30 & 24.14 & 37.76 \\
\hline
\end{tabular}

The codes of HAN, GIG, SIE, DIS, and DIV are the same as Table 1.

Table 5. The number of different bases among five species of Haliotis using ITS

\begin{tabular}{cccccc}
\hline Species & HAN & GIG & SIE & DIS & DIV \\
\hline HAN & - & & & & \\
GIG & 296 & - & & & \\
SIE & 275 & 146 & - & & \\
DIS & 30 & 219 & 259 & - & \\
DIV & 149 & 358 & 337 & 154 & - \\
\hline
\end{tabular}

The codes of HAN, GIG, SIE, DIS, and DIV are the same as Table 1.

Table 6. Genetic identity (upper diagonal) of Haliotis based on ITS and genetic distances (low diagonal) at species level

\begin{tabular}{cccccc}
\hline Codes & HAN & GIG & SIE & DIS & DIV \\
\hline HAN & - & 0.911 & 0.588 & 0.961 & 0.676 \\
GIG & 0.093 & - & 0.593 & 0.914 & 0.706 \\
SIE & 0.531 & 0.523 & - & 0.578 & 0.412 \\
DIS & 0.040 & 0.090 & 0.548 & - & 0.720 \\
DIV & 0.392 & 0.348 & 0.887 & 0.329 & - \\
\hline
\end{tabular}

The codes of HAN, GIG, SIE, DIS, and DIV are the same as Table 1. 
Although alignments of the Haliotis species were great similarity among the species' sequences, the unusual ITS1 insert were shown (Table 7). In addition, variations was shown in nucleotide substitutions and indels.

Clustering of Haliotis Species, using the NJ algorithm, was performed based on the matrix of calculated distances (Fig. 2). The phylogenic tree showed Korean species were well separated each other. When a more worldwide selection of species was included, the tree also shows genetic differentiation among Haliotis species.

All ITS trees generated exhibited partly unsolved topology with low bootstrap support irrespective of the methods (parsimony or N-J) and the setting used. This result confirmed two clades for all species. $H$ discus hannai was similar to $H$. discus, while $H$ diversicolor aquatilis was more distinct (Fig. 2). H. discus hannai and $H$. discus were supported with bootstrap values of $99 \%$.

Considering all the non-North Pacific species of Haliotus, $H$. discus hannai, $H$. discus, $H$. sieboldii, and $H$. gigantea are not conformed one group and $H$. diversicolor aquatilis is an- other (Fig. 3).

\section{Discussion}

Given the proliferation of genetic markers, comparisons between techniques are inevitable. However, there is a need technique is best suited the issues being examined. In previous study, ITS were used to determine the genetic relationships among species and the results compared to pedigree relationships where there were available [4]. With respect to particular genes and their associated regions, phylogenetic reconstructions are available for the cDNA sequences of the sperm protein lysin, the flanking 3 ' untranslated sequence of lysin [19], the $18 \mathrm{kD}$ protein related to lysin [21], and the $m t \mathrm{COI}$ gene [15]. In the North Pacific species ITS subclade (A), the foursome of California species grouped together in Fig. 3 in trees for these four additional loci. With respect to particular genes and their associated regions, phylogenetic reconstructions are available for the ITS sequence. From the ITS analyses, the Pacific species appear to be closely

Table 7. Comparison of genus Haliotis on ITS insert sequences

\begin{tabular}{|c|c|c|c|}
\hline Species & Sequences & & Reference \\
\hline All North Pacific spp. & amwc>GGGGTGCAAGCGCGCTTCTCCCC & $<\cdots \cdots \cdots \cdots \cdots \cdots \cdot \cdots \cdot \operatorname{agtcg}$ & Coleman \& Vacqier [4] \\
\hline Med-N. Atlantic spp. & 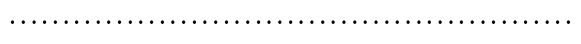 & 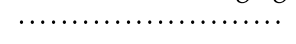 & Coleman \& Vacqier [4] \\
\hline H. midae (Africa) & agtw>GGGGTTGAAGCGCGCTTCTCCCC & $<\mathrm{C} \cdots \cdots \cdots \cdots \cdots \cdot$ gatcg & AF296863 \\
\hline H. scalaris (Australia) & agtw>GGGGTTGAAGCGCGCTTCTCCCC & $<$ GAACGC $\cdots \cdots$ gatcg & AF296864 \\
\hline H. cyclobates (Australia) & agtw>GGGGTTGAAGCGCGCTTCTCCCC & <GAACGCTCGatcg & AF296865 \\
\hline H. roei (Australia) & agtw>GGGGTTGAAGCGCGCTTCTCCCC & $<$ GAACGCTCGmtcg & AF296866 \\
\hline H. rubra (Australia) & agtw>GGGGTTGAAGCGCGCTTCTCCCC & <GAACGCTCGmtcg & AF296867 \\
\hline$H$. diversicolor supertexta (Taiwan) & ttcg>GGGGTTGAAGCGCGCTTCTACCC & $<\mathrm{A} \cdots \cdots \cdots \cdots \cdots \cdots \cdots$ & AF296868 \\
\hline$H$. iris (new Zealand) & $\cdots \cdots>$ GTTATGGC $\cdots \ldots \ldots \ldots \ldots \ldots \ldots \ldots \ldots$ & 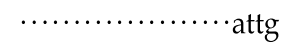 & AF296849 \\
\hline Haliotis discus hannai & cacg>GGGGTGCAAGCGCGCGCGTTCTC & $<$ CCCAGGTcg & This study \\
\hline H. gigantea & cacg>GGGGTGCAAGCGCGCGCGTTCTC & $<$ CCCAGGTcg & This study \\
\hline H. sieboldii & cacg>GGGGTGCAAGCGCGCGCGTTCTC & $<$ CCCAGGTtcg & This study \\
\hline H. discus & $\operatorname{cacg}>$ GGGGTGCAAGCACGCGC-TTCTC & $<$ CCCA-GTcg & This study \\
\hline$H$. diversicolor aquatilis & ttcg>GGGGTTGAAGCGCGCTTCTCCCA & $<$ CCCA----- & This study \\
\hline
\end{tabular}

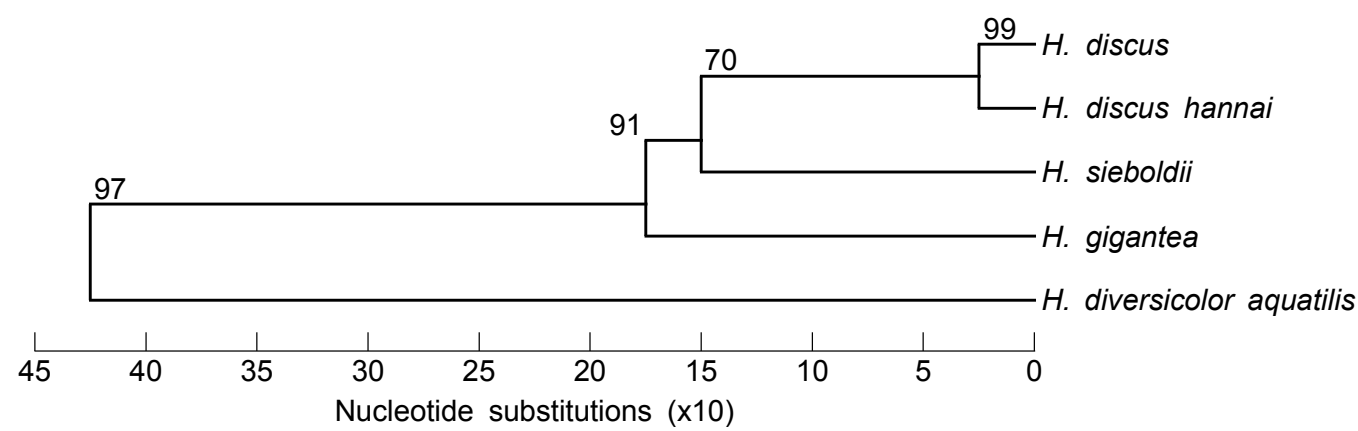

Fig. 2. Fifty percent majority rule consensus tree, obtained after 1000 bootstrap repetitions for ITS parsimony analysis (heuristic, TBR default) with gaps coded as missing. Above the lines, percent frequencies greater than 50 are shown. 


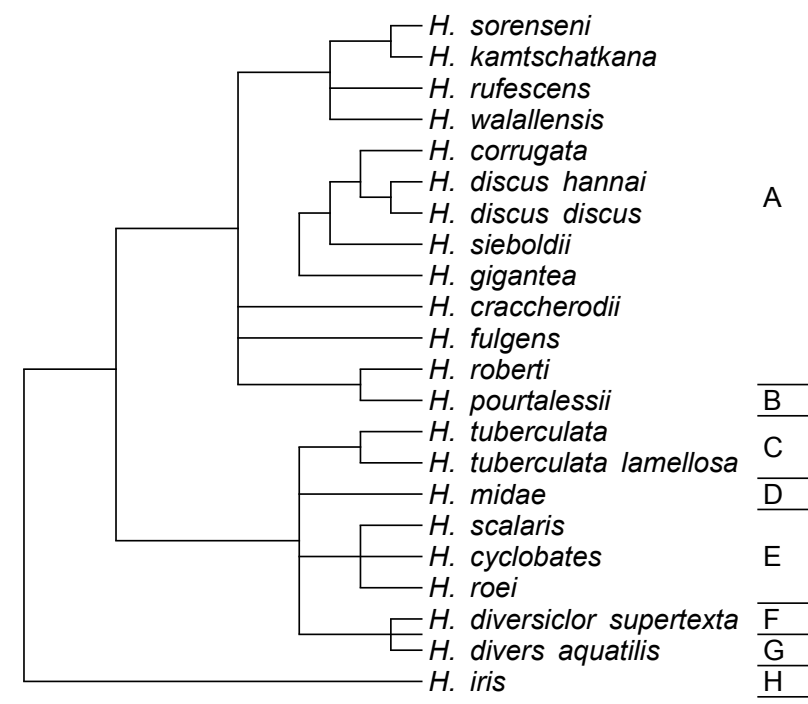

Fig. 3. A phylogenetic tree for Haliotis based on ITS analysis. A: North Pacific, B: Caribbean, C: Europe, D: Africa, F: South Australia, G: Korea, H: Taiwan, I: New Zealand

related. If so, it is of interest to examine whether they can potentially interbreed successfully. Four papers [11,12,14,21] reported the results from various experimental pairings of eight North Pacific species. These include data on frequency of fertilization in interspecies pairings and titer of lysin needed for vitellitine envelop dissolution [4]. Most reciprocal pairings, but not all, produce similar results in terms of present fertilization.

From the ITS analyses, the North Pacific species appear to be closely related. If so, it is of interest to examine whether they can potentially interbreed successfully $[14,21]$.

The branching pattern of the Taiwan-Australia-South Africa assortment of species remains unresolved [4]. The ITS analyses, one might conclude that the common ancestor of the Halioitis species had a major ITS-1 insert, and that all the North Pacific species diverged fairly recently from one ancestral type, hence their uniformity for this insert. The Mediterranean-Atlantic species is likely derived from a different ancestor, one that had lost the insert [4]. However, both the North Pacific species, $H$. diversicolor supertexta and $H$. diversicolor aquatilis in Korea have become isolated from other North Pacific species (Fig. 3). Both species are very smaller that those of other North Pacific species, It is not unsurprising of considering the morphological differences.

From the dendrogram of the species studied, a very good agreement with the existing classification based on ITS and mitochondrial DNA sequences of the species of genus Haliotis was observed [15]. First, H. discus hannai, H. discus,
$H$. sieboldii, and $H$. gigantea grouped with species of North Pacific. Secondly, H. diversicolor aquatilis is separated from the remaining Korean abalone and is both positioned just ancestral to subclade Europe and Australia in the tree.

There is a good agreement between results from ITS sequence analysis [4], although the ITS1/5.8S regions do not show enough resolution potential among several species. The ITS technique is more useful taxonomic tool for genus Haliotis species and species delineation than the ITS sequences.

\section{References}

1. Adams, R. P., A. E. Schwarzbach, and R. N. Pandey. 2003. The concordance of terpenoid, ISSR, and RAPD markers, and ITS sequences data sets among genotypes: an example from Juniperus. Biochem System and Ecol. 31, 375-387.

2. Baldwin, B. G. 1993. Molecular phylogenetics of Calcydenia (Compositae) based on ITS sequences of nuclear ribosomal DNA: Chromosomal and morphological evolution reexamined. Am J. Bot. 80, 222-238.

3. Coleman, A. W., L. Jaeenicke, and R. C. Starr. 2001. Genetics and sexual behavior of the pheromone producer, Chlamydomonas allensworthii (Chlorophyceae). J. Phycol. 37, 1-5.

4. Coleman, A. W. and V. D. Vacquier. 2002. Exploring the phylogenetic utility of ITS sequences for animals: a test case for abalone (Haliotis). J. Mol. Evol. 54, 246-257.

5. Degnan, S. M., I. Imron, D. L. Geiger, and B. M. Degnam. 2006. Evolution in temperate and tropical seas: disparate patterns in southern hemisphere abalone (Mollusca: Vetigastropod: Haliotidae). Mol. Phylogen. Evol. 41, 249-256.

6. Doyle, J. J. and J. L. Doyle. 1987. A rapid DNA isolation procedure for small quantities of fresh leaf tissues. Phyto. Bull. 19, 11-15.

7. Dubouzet, J. G. and K. Shinoda. 1999. Relationships among old and New world Alliums according to ITS DNA sequence analysis. Theor. Appl. Genet. 98, 422-433.

8. Felsenstein, J. 1993. PHYLIP (Phylogeny Inference Package) Version 3.5s, Distributed by the Author. Department of Genetics, Univ. Washington, seattle.

9. Geiger, D. L. 1998. Recent genera and species of the family Haliotidae (Gastropoda: Vetigastropoda). The Nautilus 111, 85-116.

10. Geiger, D. L. 1999. Ph. D. dissertation, University of Southern California, Los Angeles, CA, pp. 423.

11. Hoshikawa, H, Y. Sakai, and A. Kijima. 1998. Growth characteristics of the hybrid between abalone, Haliotis kamtschatkana Jonas, and ezo abalone, $H$ discus hannai Ino, under high and low temperature. J. Shellfish Res. 17, 673-677.

12. Leighton, D. L. and C. A. Lewis. 1982. Experimental hybridization in abalones. Int. J. Invert. Reprod 5, 273-282.

13. Lindberg, D. R. 1992. Evolution, distribution and systematics of Haliotidae, pp. 3-19, In Shepherd, S. A., M. J. Tegner 
and G. del Proo (eds.), Abalone of the World Biology, Fisheries and Culture. Blackwell Scientific, London.

14. Lyon, J. D. and V. D. Vacquier. 1999. Interspecies chimeric sperm lysins identify regions mediating species-specific recognition of the abalone egg vitelline envelope. Dev. Bid. 214, 151-159.

15. Metz, E. C., R. Robles-Sikisaka, and V. D. Vaquier. 1998. Nonsynonymous substitution in abalone sperm fertilization genes exceeds substitution in introns and mitochondrial DNA. Proc. Natl. Acad Sci. USA 95, 10676-10681.

16. Oliverio, M., M. Cervelli, and P. Mariottini. 2002. ITS2 rRNA evolution and its congruence with the phylogeny of muricid neogastropods (Caenogastropoda, Muriocoidea). Mol. Phylogen. Evol. 25, 63-69.

17. Saitou, N. and M. Nei. 1987. The neighbor-joining method: A new method for reconstructing phylogenetic trees. $\mathrm{Mol}$. Biol. Evol. 4, 406-425.

18. Schlötter, C., M. T. Hauser, A. van Haesler, and D. Tautz. 1994. Comparative evolutionary analysis of rRNA ITS re- gions in Drosophila. Mol. Biol. Evol. 11, 513-522.

19. Swanson, W. J. and V. D. Vacquier. 1998. Concerted evolution in an egg receptor for a rapidly evolving abalone sperm protein. Science 281, 710-712.

20. Tamura, K., J. Dudley, M. Nei, and S. Kumar. 2007. MEGA4 Molecular evolutionary genetics analysis (MEGA) software version 4.0. Mol. Biol. Evol. 24, 1596-1599.

21. Vacquier, V. D. and Y. H. Lee. 1993. Abalone sperm lysin: unusual mode of evolution of a gamete recognition protein. Zygote 1, 181-196.

22. Wrischnik, L. A., R. G. Higuchi, M. Stoneking, H. A. Erlich, N. Arnheim, and A. C. Wilson. 1987. Length mutations in human mitochondrial DNA: direct sequencing of enzymatically amplified DNA. Nucleic Acids Res. 15, 529-542.

23. White, T. J., T. Bruns, S. Lee, and J. Taylor. 1999. Amplification and direct sequencing of fungal ribosomal genes for phylogenetics, pp. 315-322, In Innis M. A., D. H. Gelfand, J. J. Sninsky, and T. J. White (eds.), PCR Protocols: A Guide to Methods and Applications, New York Academic press.

\section{초록 : ITS에 의한 한국내 전복 속 분류군의 유전적 계통분류학적 연구}

허만규 ${ }^{\star} \cdot$ 김정호 ${ }^{1} \cdot$ 문두호

(동의대학교 분자생물학과, ${ }^{1}$ 부산대학교 생물교육전공)

전복속에 속하는 종은 아시아를 포함한 세계에 광범위하게 서식한다. 전복속 종은 한국과 중국에서는 식용뿐만 아니라 약용으로도 이용된다. 한국내 전복속(genus Haliotis)에 속하는 분류군에 대해 ITS에 의한 계통관계를 조사하 였다. 전복속 전체 종에서 $5.8 \mathrm{~S}$ exon은 160 핵산서열로 일정하였다. ITS1은 종에 따라 다양하였는데, 오분자기 $(H$. diversicolor aquatilis)에서 272 핵산서열인 반면, 시볼트전복은 294 핵산서열이었다. ITS2 핵산서열 역시 종에 따라 다양하였다. 전체 서열은 오분자기는 722 핵산서열인 반면, 시볼트전복은 752 핵산서열이었다. ITS 전체 서열은 763 핵산서열에서 78 개는 절약법에 정보적이었고, 57 개는 변이로 비정보적이였고, 459 는 일정하였다. 오분자기는 다른 전복속 종과 다른 분지를 나타내었다. ITS 서열로 한국내 분류군과 유럽종간 구분이 잘 되었다. ITS 서열로 종 동정에 이용할 수 있었으며, 종의 보전이나 생식질 보전에 기초로 이용될 수 있을 것으로 사료된다. 